\title{
HUBUNGAN ANTARA TINGKAT RELIGIUSITAS DENGAN TINGKAT AKTIVITAS SEKSUAL PADA REMAJA AKHIR
}

\author{
Dya Lita Pradisukmawati, Eko Darminto \\ FIP, UNESA. \\ e-mail: deyde72@yahoo.com
}

\begin{abstract}
The purpose ofthis study was totest the relationshipbetween thedegree of religiousityandthedegree ofsexual activity among late-adolescences. The research design usedwasa quantitative using correlational analysis. The sample was30late adolescentsinthe Southarea ofSurabayawhich wereselectedusing purposive sampling. The subjects of this research were adolescents of aged 18-21 years old, were in/had been in a relationship with another person, lived in South Surabaya, were at Senior High School or University, and were willing to participate in the study. The data were collected using religiousity and sexual activity questionary that were developed by the researcher.Hypothesis was tested using statistical technique Phi correlation coefficient.To know the significant level of correlation analysis result of 0,79, Chi-Squre $\left(X^{2}\right)$ was converted with a significant level of $5 \%$, the value obtained was 3.84. Based on these result it can be seen that the Chi-Squre $\left(X^{2}\right)$ value of 18.7 is far above the value of theoretical Chi-squre, of 3.84 (5\%). From the data in Chi-Squre $\left(X^{2}\right)$ crosstab that degree of religiousity have a negative correlational with degree ofsexual activity.
\end{abstract}

Keywords: the degree of religiousity, the degree of sexual activity, adolescences

\begin{abstract}
Abstrak
Tujuan penelitian ini adalah untuk menguji ada tidaknya hubungan antara tingkat religiusitas dengan tingkat aktivitas seksual pada remaja akhir. Rancangan penelitian yang digunakan adalah kuantitatif korelasional. Sampel penelitian ini adalah 30 remaja akhir di kota Surabaya wilayah Selatan yang di pilih dengan teknik purposive sampling. Subjek penelitian ini merupakan remaja berusia 18-21 tahun, pernah/sedang menjalin hubungan dengan orang lain, berdomisili di Surabaya Selatan, bersedia mengikuti penelitian dengan menandatangani lembar persetujuan sebagai subjek penelitian dengan status SMTA dan Perguruan Tinggi. Data penelitian di kumpulkan melalui angket yaitu angket tingkat reliigusitas dengan tingkat aktivitas seksual yang dikembangkan sendiri oleh peneliti. Uji hipotesis dilakukan dengan teknik statistik koefisien kontingensi korelasi Phi (Ø)dengan hasil analisis data sebesar 0,79 dan untuk mengetahui taraf signifikan, peneliti melakukan konversi kenilaian Chi-Squre $\left(\mathrm{X}^{2}\right)$ teoritik sebesar 18,7 dengan taraf $5 \%$ yang menunjukkan 3,84 (5\%). Dari data di Chi-Squre $\left(X^{2}\right)$ crosstab bahwa tingkat religiusitas memiliki korelasi negatif dengan tingkat aktivitas seksual
\end{abstract}

Kata kunci: tingkat religiusitas, tingkat aktivitas seksual, remaja

\section{PENDAHULUAN}

Masalah seksualitas merupakan masalah yang pelik bagi remaja, karena remaja merupakan masa dimana seseorang dihadapkan pada berbagai tantangan dan permasalahanyang berasal dari diri sendiri maupun lingkungannya. Tantangan dan masalah ini berdampak pada perilaku remaja, khususnya aktivitas seksual. Kasus mengenai perilaku seksual pada remaja dari waktu ke waktu semakin meng- khawatirkan, sementara di masyara-kat terjadi pergeseran nilai-nilai moral yang semakin jauh sehingga masalah tersebut sudah menjadi suatu hal yang biasa, padahal perilaku tersebut merupakan sesuatu yang harus dihindari oleh setiap individu.

Fenomena seks yang terjadi di masyarakat tidak hanya dilakukan oleh orang dewasa, akan tetapi remaja juga telah melakukan hubungan seks di luar pernikahan, seperti pada pelajar SMP, 
SMA, dan SMK. Para remaja ini melakukan hubungan layaknya suami istri. Aktivitas seksual tidak hanya dilakukan pada remaja umum akan tetapi remaja berbasis agama juga ditemukan telah melakukan aktivitas seksual.

Peneliti melakukan observasi di luar lingkungan sekolah pada beberapa pelajar di wilayah Surabaya Selatan. Adapun hasil observasi pada perwakilan pelajar dari SMA Negeri "A" menyatakan bahwa beberapa temannya ada yang hamil di luar pernikahan karena melakukan aktivitas seksual dengan pasangannya (pacar). Di dua SMA Swasta "B dan C" jurusan IPS menyatakan bahwa mereka (siswa dan siswi) pernah melakukan aktivitas seksual dengan pasangannya dan dengan orang lain yang tidak pernah dikenal awalnya. Mereka melakukan aktivitas tersebut karena keadaan ekonomi, coba-coba, penasaran, pergaulan yang semakin bebas yang menuntut mereka untuk bersaing dengan teman-teman yang lebih baik dalam hal ekonomi, kurangnya pengawasan orang tua dan melalaikan kepercayaan orang tua. Sedangkan dua siswa dari SMA Islam "D dan E" juga menyatakan ada beberapa siswiyang melakukan aktivitas seksual karena paksaan pasangannya (pacar), namun ada beberapa juga mengatakan bukan karena paksaan melainkan rasa ingin tahu. Mereka melakukannya karena melihat film atau video porno baik melalui internet, website ataupun handphone milikteman. Pada salah satu Pondok Pesantren "F" ada beberapa santriwati pernah melakukan aktivitas seksual di luar pesantren.

Anggara (2012) menyatakan data hasil survey sikap dan perilaku seks pelajar di tahun 2012, 44\% dari 450 responden menyebutkan pacaran boleh melakukan hubungan seks. Tak hanya itu, para pelajar juga menyebutkan bahwa tayangan televisi merupakan sumber inspirasi untuk melakukan hubungan seks.

Fakta tersebut menunjukkan data yang memprihatinkan mengenai aktivitas seksual pada remaja yang tahun ke tahun semakin mengkhawatirkan dan meningkat. Hal tersebut menunjukkan bahwa telah terjadi pergesaran aktivitas seksual di kalangan remaja.

Penelitian yang dilakukan oleh Yayasan keluarga Kasier (dalam Dariyo, 2004) mengungkapkan hal-hal yang mendorong terjadinya aktivitas seksual. Pertama adalah kematangan biologis, dimana seorang remaja sudah dapat melakukan fungsi reproduksi layaknya orang dewasa dan fungsi organ seksualnya telah bekerja secara normal. Kedua adalah faktor mispersepsi terhadap pacaran. Seringkali remaja mempunyai pandangan yang salah bahwa masa pacaran merupakan masa dimana boleh mencintai dari ungkapan kasih sayang, rasa cinta, misalkan memberi coklat atau bunga, berpelukan, berciuman, dan bahkan melakukan hubungan seksual. Hal inilah yang salah, karena sebelum pacaran sebaiknya orang tua wajib memberi tahu dan pengertian agar remajanya tidak terjerumus pada hal-hal yang tidak diinginkan. Ketiga adalah religiusitas kehidupan beragama yang baik dan benar ditandai dengan pengertian, pemahaman, dan ketaatan dalam menjalankan ajaran agama yang baik tanpa terpengaruh kondisi apapun. Individu yang taat beragama dapat menepatkan diri dan mengendalikan diri agar tidak berbuat hal yang bertentangan ajaran agama. Sebaliknya, remaja yang rapuh imannya cenderung mudah melakukan pelanggaran terhadap ajaran agama. Agama hanya dijadikan topeng untuk mengelabui pacar dan orang lain. Sehingga tidak heran kemungkinan besar individu dapat dan sudah melakukan hubungan seksual.

Walaupun ada keanekaragaman agama, namun ajaran agama tidak mendukung adanya aktivitas seksual. Meski demikian acara keagamaan bukan suatu jaminan mutlak untuk seseorang tidak melakukan kesalahan secara seksual dan sosial, tetapi tidak memberi kontribusi yang positif bagi pertumbuhan nilai-nilai moral, etik dan spiritual yang diyakini 
banyak kalangan dan menjadi penangkal penyimpangan aktivitas seksual (Santrock, 2002).

Kualitas religius masyarakat Indonesia yang baik akan memberi kontribusi yang positif bagi bertumbuhnya nilai-nilai moral, etik dan spiritual yang diyakini banyak kalangan dan menjadi penangkal untuk melakukan aktivitas seksual. Akan tetapi dalam kenyataan kualitas religius masyrakat Indonesia masih belum memuaskan dan masih timpang yang dapat menyebabkan masyarakat Indonesia menjadi merosot yang dikarenakan kalangan remaja yang tidak memiliki tingkat religius yang kuat sehingga dengan mudah menyerap budaya barat yang tidak sesuai dengan budaya Indonesia salah satunya adalah pergaulan bebas dan melakukan aktivitas seksual dengan pasangan / orang lain (Djarir, dalam Daradjat, 1991).

Penyebab dari rendahnya kualitas religius disebabkan karena remaja mulai rendah mengkaji ilmu agama pada masa kanak-kanak dan proses remaja merupakan sebagai periode keraguan religius. Wagner berpendapat "banyak remaja menyelidiki agama sebagai sumber dari rangsangan emosional dan intelektual. Para remaja ingin mempelajari agama berdasarkan intelektual dan tidak ingin menerima dengan mudah. Para remaja meragukan agama bukan karena menjadi agnothis atau atheis melainkan karena ingin menerima agama sebagai suatu yang bermakna berdasarkan kegiatan untuk kemadirian dan bebas untuk menentukan keputusan yang dibuat sendiri" (Hurlock, 2010).

Fowler (dalam Santrock, 2002) berpendapat dan mengajukan pandangan yang berbeda dimana, perkembangan pada masa remaja akhir merupakan masa yang penting karena untuk pertama kalinya individu memiliki tanggung jawab penuh akan keyakinan religiuasnya dan percaya bahwa perkembangan nilai moral berhubungan dengan perkembangan nilai religiusnya. Di Indonesia agama dipandang sebagai tolak ukur tingkah laku seseorang. Anggapan umum yang berlaku bahwa semakin tinggi nilai religiusnya makin terkendali tingkah lakunya khususnya hal-hal yang me-nyimpang norma-norma agama (Daradjat, 1991).

Para remaja Indonesia saat ini harus dihadapakan dengan dua nilai yang saling bertentangan yaitu nilai religius yang melarang dan nilai sekuler yang memperbolehkan aktivitas seksual. Ini berdampak dari arus globalisasi karena masuknya informasi yang tak terbatas. Adanya pertentangan nilai religious dan sekuler semakin menambah konflik ke-raguan pada remaja Indonesia tentang religius (Daradjat, 1991).

Remaja yang tidak mampu mengendalikan diri karena religius rendah akan terlibat dalam kehidupan seksual, misalnya seks bebas atau seks di luar pernikahan (Dariyo, 2004). Hal ini menimbulkan masalah bagi remaja, orang tua, tempat pendidikan, dan menjadi masalah bangsa Indonesia. Masalah yang timbul ketika terjangkit penyakit menular, melakukan aborsi, kehamilan yang tidak diinginkan dan tak terduga. Hal ini yang menjadi salah satu konsekuensi remaja untuk drop out (putus sekolah atau berhenti tidak kuliah) dari dunia pendidikan atau Universitas.

Adanya permasalahan aktivitas seksual hal inilah yang membuat peneliti untuk mengangkat beberapa variabel diatas sebagai hal-hal yang diungkap. Untuk itu perlu menelaah kembali tentang "Hubungan antara Tingkat Religiusitas dengan Tingkat Aktivitas Seksual pada Remaja Akhir". Aktivitas seksual yang dilakukan remaja akhir dinilai sebagai sesuatu yang menyimpang dari nilai agama, seharusnya nilai keagamaan yang dianut dapat mengkontrol seksual pada remaja akhir. Diharapkan hasil dari penelitian ini dapat menjadi referensi untuk menyikapi aktivitas seksual di Surabaya Selatan yang semakin meningkat di setiap tahunnya. 


\section{METODE}

Metode penelitian yang digunakan adalah penelitian kuantitatif dengan rancangan korelasional yang bertujuan untuk meneliti sejauh mana kaitan antara variabel satu dengan variabel lain berdasarkan koefisien korelasi. Variabel bebas pada penelitian ini berupa tingkat religiusitas. Variabel terikat pada penelitian ini berupa tingkat aktivitas seksual.

Populasi dalam penelitian ini adalah pelajar/mahasiswa yang tinggal di Surabaya, berusia 18-21 tahun, serta yang pernah menjalin hubungan dengan orang lain.Pengambilan sampel dilakukan dengan menggunakan teknik purposive sampling, yaitu teknik pengambilan sampel berdasarkan karakteristik tertentu yang sudah diketahui dan ditentukan melalui cirri dan sifat populasinya. Subjek penelitian yang dijadikan sampel penelitian sebanyak 30 subjek..

Instrumen yang digunakan dalam penelitian ini adalah skala psikologi, yaitu skala dependensi dan skala persepsi terhadap pola pengasuhan orang tua. Instrumen yang digunakan untuk membedakan jenis kelamin menggunakan metode dokumentasi.

Skala tingkat religiusitas memiliki lima indikator yaitu religious practice (praktek religius), religious belief (keyakinan religius), religious knowledge (pengetahuan religius), religious feeling (perasaan religius), religious effect (pengaruh/akibat/konsekuensi religius). Skala Tingkat Religiusitas digunakan untuk mengungkap sejauhmana tingkat religiusitas yang dimiliki subjek penelitian.Skala tingkat religiusitas ini berjumlah 41 aitem pernyataan yang terdiri 22 pernyataan favourable dan 19 aitem pernyataan unfavourable.

Skala kepribadian Tingkat Aktivitas Seksual memiliki empat yaitu heterosexuality ringan, heterosexuality petting, auto-sexuality mastrubasi, dan heterosexuality intercourse.Skala Tingkat
Aktivitas Seksual digunakan untuk mengungkap sejauhmana tingkat aktivitas seksual yang dimiliki subjek penelitian. Skala tingkat aktivitas seksual ini berjumlah 16 aitem pernyataan yang terdiri 16 pernyataan favourable.

Teknik analisis data yang digunakan dalam penelitian ini adalah teknik analisis varian dua jalur dengan uji asumsi normalitas dan homogenitas. Hasil uji asumsi menunjukkan bahwa data penelitian layak untuk diuji dengan analisi varian dua jalur.

\section{HASIL DAN PEMBAHASAN}

Hasil

Berdasarkan hasil ini maka dapat dilihat bahwa konversi kenilaian ChiSqure sebesar 18,7 jauh berada di atas nilai Chi-Squre teoritik dengan taraf signifikansi 5\% menunjukkan angka 3,84 dan pada taraf $1 \%$ menunjukkan angka 6,63. Hasil penelitian menunjukkan bahwa bahwa hipotesis diterima dan ada hubungan yang signifikansi antara tingkat religiusitas dengan tingkat aktivitas seksual pada remaja akhir.

\section{Pembahasan}

Teknik korelasi Phi (Error! Reference source not found. untuk mencari hubungan atau korelasi antara dua variabel independen dengan variabel dependen. Variabel independen pada penelitian ini adalah tingkat religiusitas dan variabel dependen pada penelitian ini adalah tingkat aktivitas seksual.

Penelitian yang dilakukan pada remaja yang memenuhi kriteria penelitian ini bertujuan untuk mengetahui mencari hubungan antara tingkat religiusitas dengan tingkat aktivitas seksual pada remaja akhir.

Pada dasarnya religiusitas merupakan hal yang menyangkut derajat manusia untuk menjadi seseorang yang benar-benar taat beragama. Jalaludin (2002) mendefinisikan religiusitas sebagai suatu keadaan yang ada dalam diri individu yang mendorongnya untuk bertingkah laku 
sesuai dengan kadar ketaatannya terhadap agamanya.

Menurut Dariyo (2004), religiusitas saat ini dipengaruhi oleh kehidupan iman yang tidak baik. Hal ini yang mempengaruhi para remaja akhir untuk melakukan hal-hal yang diluar batas norma agama. Walaupun ada keanekaragaman agama, sebagian besar ajaran agama tidak mendukung hubungan seks di luar pernikahan. Remaja yang sering menghadiri ibadah keagamaan juga meningkatkan kemungkinan berteman dengan remaja yang memiliki sikap yang tegas terhadap seks.

Ciri-ciri remaja yang memiliki tingkat religiusitas tinggi dapat dilihat dari tingkah laku, sikap, perkataan serta seluruh jalan hidupnya yang mengikuti ajaran agama. Religiusitas akan menjadi norma dalam hidupnya yang membatasi dan mengendalikan aktivitas seksual. Remaja menganggap bahwa aktivitas yang dilakukan tidaks sesuai dengan ajaran agamanya adalah suato dosa yang akan berusaha untuk tidak melakukan aktivtas seksual yang dianggap dosa. Remaja memiliki keyakinan banwa apabila melakukan sesuatu yang dilarang agama maka akan berdosa.

Demikian juga dengan remaja yang memiliki tingkat religiusitas tinggi maka keyakinan serta ketaatan terhadapa ajaran agama akan mengendalikan aktivitasnya terutama aktivitas seksual, karena remaja mengalami kematangan seksual. Hormone seksualnya mengalami perubahan yang ditandai dengan timbulnya rasa tertarik dengan lawan jenis, mulai menjalin hubungan yang lebih dalam berteman.

Perubahan hormon seksual ini yang menyebabkan munculnya dorongan seksual yang kuat. Remaja yang tidak memiliki tingkat keyakinan yang kuat ajaran agama atau norma, tidak memiliki batasan dalam beraktivitas, apa yang boleh dilakukan atau yang tidak boleh dilakukan. Aktivitas seksual yang dimunculkan akan cenderung tinggi.
Remaja yang memiliki keyakian yang kuat terhadap ajaran agama akan memiliki tolak ukur tentang apa yang boleh dilakukan dan tidak boleh dilakukan. Remaja memiliki keyakinan bahwa aktivitas seksual adalah sesuatu yang dilarang agama. Maka remaja membuat batasan-batasan untuk dirinya sendiri mengenai aktivitas seksual dalam berhubungan dnegan pacar atau kekasih, teman dan orang lain yang baru dikenal.

Hal tersebut mendorong remaja akan menghindari hal-hal atau situasi yang dapat memunculkan dorongan seksual yang kuat. Remaja akan berkata tidak atau menolak untuk melakukan aktivitas tersebut yang dilarang agamanya.

Adapun penelitian tambahan dilakukan dengan cara wawancara, dimana semua subjek melakukan aktivitas seksual dengan pacar/kekasih, teman sendiri dan orang lain yang baru dikenalnya dan merasa ketagihan setelah melakukannya. Akan tetapi, ada dua atau tiga subjek melakukan aktivitas seksual karena kebutuhan ekonomi. Para subjek penelitian ini melakukan kegiatan aktivitas seksual secara sadar dan tanpa paksaan dari orang lain. Mereka melakukannya karena terpengaruh lingkungan sekitar, keadaan ekonomi keluarga, rasa ingin tahu dan coba-coba. Keadaan religiusitas para subjek dikatakan sedang atau lumayan. Mereka tetap menjalani kegiatan agama setiap minggunya akan tetapi mereka juga melakukan kegiatan aktivitas tersebut.

Hal ini sesuai dengan penelitian yang dilakukan oleh Yayasan Keluarga Kaiser (Kaiser Family Foundation, dalam Dariyo, 2004), dimana aktivitas ini terjadi karena tiga hal yaitu pertama adalah bentuk penyaluran kasih sayang dalam masa pacaran. Dimana para remaja seringkali memandang hubungan pacaran bentuk ungkapanya dengan melakukan aktivitas seksual, berpelukan dan berciuman.

Kedua adalah kehidupan iman dalam beragama, dimana kehidupan beragama yang baik dan benar ditandai dengan 
pengertian, pemahaman, dan kataatan dalam menjalankan ajaran agama dengan baik tanpa dipengaruhi kondisi apapun. Akan tetapi remaja yang tingkat religiusitasnya rendah atau sedang mudah melakukan pelanggaran terhadap ajaran agama yang hanya dijadikan sebagai kedok atau topeng untuk mengelabui orang lain (pacar). Sehingga tidak heran, kemungkinan besar para remaja dapat melakukan kegiatan aktivitas seksual.

Ketiga adalah ditandai dengan adanya kematangan biologis. Dimana para remaja dapat melakukan fungsi reproduksi se-bagaimana layaknya orang dewasa lainnya. Hal ini yang membawa konsekuensi remaja mudah terpengaruh oleh stimulasi yang merangsang gairah seksualnya dengan melihat media baik internet, film dan cerita-cerita tentang perkosaan. Kematangan biologis remaja yang tidak disertai dengan kemampuan mengendalikan diri cenderung akan berakibat negatif. Sebaliknya, kematangan biologis remaja yang disertai dengan kemampuan mengendalikan diri cenderung akan berdampak positif.

Berdasarkan data yang didapat dari penelitian ini, menunjukkan dari subjek penelitian yang berjumlah 30 remaja akhir, ternyata tingkat religiusitas memiliki hubungan dengan tingkat aktivitas seksual, karena keadaan religiusitas tinggi subjek dengan keadaan aktivitas seksual rendah. Dalam penelitian ini menemukan bahwa keadaan tingkat religiusitas seseorang tidak mempengaruhi untuk melakukan aktivitas seksual.

Hal ini sesuai dengan kondisi agama yang melarang adanya pergaulan yang bebas pada remaja yang melawan asas dalam beragama baik dalam praktek, keyakinan, pengetahuan, pengalaman, dan pengaruh religious seseorang. Hal ini yang mempengaruhi seseorang untuk melakukan aktivitas seksual baik dari teman, rendahnya tekanan lingkungan, kurangnya seseorang menghargai agama secara spiritualitas.
Masih banyak yang dapat mempengaruhi atau berhubungan dengan aktivitas seksual ataupun dengan religiousitas salah satunya adalah komunikasi keluarga, pendidikan keluarga dan lain-lainnya. Penelitian ini hanya memfokuskan pada variabel religiusitas karena keterbatasan kemampuan, maka faktor tersebut belum teramati dalam penelitian ini.

\section{SIMPULAN}

Berdasarkan hasil penelitian dan pembahasan dapat ditarik kesimpulan bahwa ada hubungan yang signifikansi antara tingkat religiusitas dengan tingkat aktivitas seksual pada remaja akhir dan religiusitas tidak mempengaruhi perilaku seseorang untuk melakukan aktivitas seksual.

\section{Saran}

Berdasarkan penelitian yang telah didapatkan, maka dikemukakan beberapa saran yang berkaitan dengan hasil penelitian, yaitu :

Berdasarkan penelitian yang telah didapatkan, maka dikemukakan beberapa saran yang berkaitan dengan hasil penelitian, yaitu :

1. Bagi Remaja Akhir

Sebagai pandangan dan pembelajaran bahwa berhubungan atau bergaul dengan orang lain baik berpacaran ataupun tidak berpacaran agar lebih berhati-hati dan menjaga diri sendiri dapat mengartikan aktivitas seksual dengan makna dan arti yang sesungguhnya dalam berhubungan dengan orang lain. Hendaknya orang tua lebih bersifat terbuka dalam membicarakan masalahmasalah seksual kepada remajanya.

2. Peneliti Selanjutnya

a. Disarankan agar penelitian selanjutnya lebih memperhatikan variabelvariabel lain selain tingkat religiousitas dengan tingkat aktivitas seksual.

b. Berkaitan dengan subjek penelitian, hendaknya diambil subjek lebih dari 30 subjek. 


\section{DAFTAR PUSTAKA}

Anggara, N. 2012. Inspirasi Seksual Remaja Bersumber dari Tayangan Teve.Detik-Surabaya.

http://news.detik.com/surabaya/read/2012/ $12 / 30 / 151529 / 2129$

802/466/inspirasi-seksual-remajabersumber-dari-tayangan-teve, diakses tanggal 05 Mei 2013.

Dariyo, A. 2004. Psikologi Perkembangan Remaja. Bogor: Ghalia Indonesia.

Daradjat, Z. 1991. Kesehatan Mental. Jakarta: PT. Gunung Agung.
Hurlock, E. B. 2010. Psikologi Perkembangan: Suatu Pendekatan Sepanjang Rentang Kehidupan (Terjemahan Istiwidayati dan Soedjarwo). Edisi kelima. Jakarta: Erlangga.

Jalaluddin, R. 2002. Pengantar Psikologi Agama. Edisi Revisi. Jakarta: PT. Raja Grafindo Persada.

Santrock, J W. 2002. Life-Span Development: Perkembangan Masa Hidup. Jakarta : Erlangga. 